\title{
PENGARUH DIVIDEN, UTANG, DAN PROFITABILITAS TERHADAP NILAI PERUSAHAAN PROPERTY DI BURSA EFEK INDONESIA (BEI)
}

\author{
I Made Dharma Putra Utama ${ }^{1}$ \\ I Made Dana ${ }^{2}$ \\ ${ }^{1,2}$ Fakultas Ekonomi dan Bisnis Universitas Udayana (Unud), Bali, Indonesia \\ e-mail: dedharmaputrautama@gmail.com
}

\begin{abstract}
ABSTRAK
Analisis laporan keuangan dilakukan untuk mengetahui tingkat kesehatan perusahaan tersebut. Sektor properti dan real estate merupakan salah satu sektor terpenting di suatu negara. Hal ini dapat dijadikan indikator untuk menganalisis kesehatan ekonomi suatu negara. Industri properti dan real estate merupakan salah satu sektor yang memberikan sinyal jatuh atau sedang bangunnya perekonomian suatu negara. Hal ini menandakan bahwa semakin banyak perusahaan yang bergerak dibidang sektor properti dan real estate mengindikasikan semakin berkembangnya perekonomian di Indonesia. Penelitian ini bertujuan untuk mengetahui pengaruh dividen, utang, dan profitabilitas terhadap nilai perusahaan pada Perusahaan Property di Bursa Efek Indonesia pada tahun 2012-2016. Berdasarkan hasil analisis yang telah dilakukan, didapat hasil yakni kebijakan dividen yang diwakilkan oleh DPR, kebijakan utang yang diwakilkan oleh DER, profitabilitas yang diwakilkan oleh ROE, mendapatkan hasil positif signifikan terhadap nilai perusahaan.
\end{abstract}

Kata kunci: $D P R, D E R, R O E$, nilai perusahaan

\begin{abstract}
Financial report analysis is conducted to determine the health level of the company. The property and real estate sector is one of the most important sectors in a country. This can be used as an indicator to analyze the economic health of a country. The property and real estate industry is one sector that signals a fall or the development of a country's economy. This indicates that more and more companies engaged in the property and real estate sector indicate the growing economy in Indonesia. This study aims to determine the effect of dividends, debt, and profitability on firm value on Property Companies on the Indonesia Stock Exchange in 2012-2016. Based the results of the analysis that has been done, the results obtained are dividend policy represented by the House of Representatives, the debt policy represented by DER, profitability represented by ROE, get a significant positive result on firm value.
\end{abstract}

Keyword: DPR, DER, ROE, firm value 
I Made Dharma Putra Utama, Pengaruh Dividen,Utang ...

\section{PENDAHULUAN}

Peningkatan bisnis di bidang properti sudah dirasakan di ibukota negara, tetapi akibat pertumbuhan ekonomi yang baik hal ini juga mempengaruhi pasar properti di luar kawasan ibukota. Seperti yang diungkapkan oleh pemimpin portal Lamudi yang melakukan pengamatan tingkat pertumbuhan ekonomi nasional Indonesia, yakni sekitar 6-7\%. Sementara itu bisnis properti di Indonesia terus mengalami peningkatan, dengan permintaan yang sangat tinggi bidang properti membuat para investor terus berdatangan ke Indonesia, apalagi dengan didukung pertumbuhan ekonomi yang sangat stabil, membuat Indonesia menjadi incaran para investor properti.

Ketertarikan investor asing dalam penanaman modal pada perusahaanperusahaan tersebut dapat dikarenakan dengan nilai perusahaan yang tinggi. Menurut Wira Adi Darmawan (2013) dikatakan bahwa nilai perusahaan diartikan sebagai harga yang bersedia dibayar oleh para calon investor seandainya suatu perusahaan akan dijual. Pemegang saham akan cenderung memaksimalkan nilai saham dan memaksa manajer untuk bertindak sesuai dengan kepentingannya melalui pengawasan-pengawasan yang akan dilakukannya. Dari segi kreditur akan cenderung berusahan untuk melindungi dana yang sudah diinvestasikan kedalam sebuah perusahaan dengan jaminan dan kebijakan pengawasan yang ketat pula terhadap perusahaan. Dalam hal ini manajer juga memiliki dorongan untuk memenuhi kepentingan pribadinya.

Optimalisasi nilai perusahaan ini dapat dicapai dengan cara melakukan tiga fungsi keuangan dimana satu keputusan keputusan keuangan yang diambil akan 
mempengaruhi keputusan keuangan yang lain dan akan berdampak pada nilai perusahaan. Weston dan Copeland (1995:5) menyatakan bahwa fungsi dari manajemen keuangan mencakup tiga keputusan keuangan penting yakni keputusan investasi, keputusan pendanaan, dan keputusan dividen. Kombinasi yang optimal atas ketiga keputusan keuangan itu akan memaksimumkan nilai perusahaan yang selanjutnya akan meningkatkan kekayaan para pemegang saham itu sendiri.

Penelitian ini akan menggunakan sektor Property, Real Estate \& Building Construction karena pada sektor ini memiliki pergerakan harga paling rendah diantara sektor yang lain sedangkan harga property semakin hari semakin mahal. Hal inilah yang menjadi dasar pertimbangan minat peneliti untuk meneliti sektor ini. Karena perkembangan sektor Property, Real Estate, \& Building Construction merupakan salah satu indikator dari pertumbuhan ekonomi suatu negara. Investasi pada sektor property merupakan investasi yang menjanjikan di masa yang akan datang dan hampir menjadi pilihan investasi yang aman bagi setiap investor, akan tetapi aktivitas perdagangan pada sektor Property, Real Estate \& Building Construction rendah.

Nilai perusahaan dapat mencerminkan nilai aset yang dimiliki perusahaan seperti surat-surat berharga. Menurut Nani Martikarini (2014), nilai perusahaan terutama perusahaan publik akan terlihat pada tinggi rendahnya harga saham. Harga saham yang tinggi akan mengakibatkan nilai perusahaan akan meningkat. Kenaikan harga saham dipicu oleh semakin tingginya penilaian investor atas saham tersebut. Begitu juga yang diungkapkan oleh Titin Herawati (2013) penilaian para investor atas saham di sebuah perusahaan salah satunya dipengaruhi oleh return yang 
diberikan oleh perusahaan tersebut. Kenaikan harga saham dipicu oleh semakin tingginya penilaian investor atas saham tersebut. Disisi lain, kenaikan harga saham otomatis akan meningkatkan kemakmuran para pemegang saham apabila terjadi kenaikan harga pasar saham maka nilai perusahaan pun akan meningkat.

Semakin tinggi harga saham sebuah perusahaan, maka semakin tinggi pula kemakmuran para pemegang sahamnya (Alfredo Mahendra Dj, 2011). Nilai perusahaan yang sudah go public di pasar modal dapat dilihat dari harga saham perusahaan tersebut, sedangkan pengertian nilai perusahaan yang belum go public nilainya terealisasi apabila perusahaan akan dijual (total aktiva) dan prospek perusahaan, risiko usaha, lingkungan usaha dan lain-lain. Farah Margaretha (2004:1).

Salah satu fenomena penurunan harga saham yang berpengaruh terhadap nilai perusahaan terjadi pada PT. Bakrieland Development Tbk (ELTY) yang mengalami kejatuhan. Perusahaan properti ini mengalami kemerosotan 18,87\% di level Rp. 129 per lembar, jauh dari harga yang ditetapkan pada rencana right issue, Rp. 160 per lembar. Sepanjang tahun 2010, perusahaan ini telah menurun 33,16\%. Saham perusahaan tersebut dikabarkan terus mengalami penurunan, seperti data yang didapat pada tahun 2012 bahwa saham PT Bakrieland Development Tbk (ELTY) turun 54,62\% menjadi Rp. 54 per saham. Di semester I-2012, Bakrieland mengalami kerugian yang dapat diatribusikan ke pemilik entitas induk senilai Rp 34,59 miliar. Padahal, di semester I-2011, ELTY masih mendapatkan laba yang dapat diatribusikan ke pemilik entitas induk mencapai Rp. 126,13 miliar. Adapun kerugian tahun berjalan di semester I-2012 mencapai Rp. 81,16 miliar. Sedangkan, 
di periode yang sama di tahun sebelumnya masih mencatat laba berjalan senilai Rp. 180,90 .

Pada fenomena di atas tersebut, terdapat beberapa faktor yang berpengaruh terhadap nilai perusahaan. Beberapa peneliti seperti Rika Susanti (2010), Indah Yunita (2011), Bambang Aji Sakti Utomo (2009), dan Ika Fanindya Jusriani (2013) berpendapat bahwa corperate governance, ownership structure, cash holding, profitabilitas, resiko finansial, investment opportunity, divident payout ratio, kebijakan hutang, ukuran perusahaan, dan kepemilikan manajerial berpengaruh terhadap nilai perusahaan. Berdasarkan faktor-faktor yang di atas, maka peneliti hanya meneliti faktor kebijakan dividen, kebijakan hutang, dan profitabilitas yang berpengaruh terhadap nilai perusahaan.

Kebijakan deviden dapat dihubungkan dengan nilai perusahaan. Kebijakan dividen merupakan salah satu faktor yang berpengaruh terhadap nilai perusahaan. Menurut Titin Herawati (2013) besarnya dividen yang dibagikan oleh perusahaan dapat memepengaruhi harga saham karena menurut Theory Bird In Hand investor lebih menyukai pengembalian yang berasal dari dividen dibandingkan dengan capital gain. Pembayaran dividen yang lebih besar tidak selalu dapat meningkatkan harga saham perusahaan. Berdasarkan teori preferensi pajak pembayaran dividen yang rendah juga dapat meningkatkan harga saham.

Kebijakan deviden dapat dianggap sebagai salah satu komitmen perusahaan untuk membagikan sebagian laba bersih yang diterima kepada para pemegang saham (Suad Husnan, 2006). Deviden tersebut yang menjadi alasan oleh investor ketika menanamkan dana untuk investasi. Perusahaan dalam membagikan deviden 
I Made Dharma Putra Utama, Pengaruh Dividen,Utang ...

mempertimbangkan proporsi pembagian antara pembayaran kepada para pemegang saham dan reinvestasi dalam perusahaan. Di satu sisi, laba ditahan (retaining earnings) merupakan salah satu sumber pendanaan (hutang) yang sangat signifikan bagi pertumbuhan perusahaan, tetapi di sisi lain deviden merupakan aliran kas yang dibagikan kepada para pemegang saham.

Kebijakan deviden menyangkut penggunaan laba yang menjadi hak pemegang saham, karena pada dasarnya laba tersebut bisa dibagi sebagai deviden atau ditahan untuk diinvestasikan kembali (Taswan, 2003).

Perusahaan yang memiliki pertumbuhan tinggi dan mempunyai kesempatan besar, akan lebih mungkin untuk membayar deviden yang rendah, karena adanya kesempatan untuk mendapatkan keuntungan dalam mendanai investasinya dengan dana internal. Perusahaan akan membayar deviden yang rendah sebab manajemen optimis bahwa perusahaan di masa yang akan datang akan menggunakan laba ditahan untuk ekspansi (Taswan, 2003).

Faktor lain yang berpengaruh terhadap nilai perusahan adalah kebijakan hutang. Kebijakan hutang merupakan kebijakan yang dikeluarkan dalam penentuan seberapa besar hutang yang akan dipinjam dalam pemenuhan kebutuhan perusahaan. Secara umum, apabila perusahaan sudah memiliki hutang yang besar maka hal ini dapat berdampak negatif terhadap nilai perusahaan di mata para investor. Jika tingkat hutang suatu perusahaan berada di bawah target, maka perlu dilakukan ekspansi dengan pinjaman, sementara jika rasio hutang sudah melampaui target, barangkali saharm perlu dijual. Resiko makin tinggi adalah mekin 
membesarnya hutang maka dapat mengakibatkan harga saham menurun (Sri Sofyaningsih, 2011).

Sementara faktor ketiga yang mempengaruhi nilai perusahaan adalah profitabilitas. Profitabilitas merupakan salah satu kemampuan perusahaan dalam menghasilkan laba selama periode tertentu. Secara umum para investor akan menanam saham mereka di perusahaan yang dapat menghasilkan profit yang besar. Dan dapat pula terjadi sebaliknya yaitu para investor akan menarik dana mereka apabila perusahaan tersebut memiliki tingkat profit yang rendah.

Dimana nantinya nilai perusahaan dapat dilihat dari tingkat profit yang dicapai oleh perusahaan tersebut. Perusahaan yang cenderung menghasilkan laba yang tinggi akan memiliki nilai perusahaan yang tinggi pula, begitu juga sebaliknya yang terjadi laba yang rendah dapat juga mengakibatkan nilai perusahaan yang rendah dalam pandangan para pemegang saham. Jika manager dalam suatu perusahaan mampu memperkecil biaya yang dikeluarkan maka profit yang didapat akan besar. Besar dan kecilnya profit ini akan dapat mempengaruhi nilai perusahaan (Titin Herawati, 2013).

Profitabilitas ialah hasil bersih dari serangkaian kebijakan dan keputusan manajemen. Oleh karena itu ratio ini menggambarkan hasil akhir dari kebijakan dan keputusan-keputusan operasional perusahaan. Salah satu cara untuk mengukur ratio profitabilitas dengan tingkat hasil seluruh modal (Return On Equity/ROE). Perusahaan dengan ukuran lebih besar memiliki pertumbuhan yang lebih besar dibandingkan perusahaan kecil. Suatu perusahaan besar yang sudah maupun akan memiliki akses yang mudah menuju pasar modal, sementara perusahaan yang baru 
dan yang masih kecil akan mengalami banyak kesulitan untuk memiliki akses ke pasar modal. Karena kemudahan akses ke pasar modal cukup berarti untuk fleksibilitas dan kemampuannya untuk memperoleh dana yang lebih besar, sehingga perusahaan mampu memiliki rasio pembayaran dividen yang lebih tinggi dibandingkan perusahaan kecil (Alli, dalam Hanafi dan Halim, 2009).

Beberapa penelitian yang menjadi rujukan dalam penelitian antara lain dilakukan oleh Taswan (2003), Sujoko (2007); Yulius Christiawan dan Joshua Tarigan (2007); Andri Rachmawati dan Hanung Triatmoko (2007); Intan Rachmawati dan Akram (2007). Penelitian Taswan (2003) memperoleh bahwa kebijakan hutang berpengaruh positif terhadap nilai perusahaan, kebijakan deviden berpengaruh negatif terhadap nilai perusahaan dan insider ownership berpengaruh positif terhadap nilai perusahaan. Penelitian oleh Sujoko dan Ugy Soebiantoro (2007) menemukan bahwa struktur kepemilikan, faktor intern, faktor ekstern dan kebijakan hutang (leverage) berpengaruh positif terhadap nilai perusahaan. Penelitian yang dilakukan Yulius Christiawan dan Joshua Tarigan (2007) diperoleh bahwa terdapat perbedaan antara kebijakan hutang dan nilai perusahaan antara perusahaan dengan kepemilikan manajerial dan perusahaan tanpa kepemilikan manajerial. Penelitian yang dilakukan Andri Rachmawati dan Hanung Triatmoko (2007) diperoleh hasil bahwa manajemen labadan KAP tidak berpengaruh terhadap nilai perusahaan; sedangkan IOS, komite audit, dan komisaris independen, ukuran perusahaan, kebijakan hutang (leverage), kepemilikan manajerial dan berpengaruh terhadap nilai perusahaan. 
Vinola Herawaty (2008) dengan hasil penelitian menunjukkan bahwa earnings management berpengaruh secara signifikan dan negatif terhadap nilai perusahaan. Variabel Corporate Governance yang mempunyai pengaruh yang signifikan terhadap Nilai perusahaan. Variabel Komisaris Independen dan Kepemilikan Institusional berpengaruh signifikan terhadap Nilai perusahaan. Kualitas Audit dan Kepemilikan Manajerial berpengaruh signifikan terhadap Nilai Perusahaan. Hastuti (2005) menemukan bahwa tidak terdapat hubungan yang signifikan antara struktur kepemilikan dengan nilai perusahaan; tidak terdapat hubungan yang signifkan antara manajemen laba dengan nilai perusahaan. Intan Rachmawati dan Akram (2007) dalam penelitiannya yang berjudul Faktor-faktor yang Mempengaruhi Kebijakan Dividen dan Pengaruhnya terhadap nilai perusahaan pada perusahaan di $B E J$ periode 2000- 2004.

Hasil penelitian diperoleh bahwa ukuran perusahaan, pertumbuhan laba, kas (aktiva lancar), dan inflasi tidak berpengaruh signifikan terhadap nilai perusahaan. Hanya variabel profitabilitas dan DPR yang berpengaruh positif terhadap nilai perusahaan. Dari penelitian terdahulu di atas terdapat hasil penelitian yang berbedabeda (gap research) dimana hasil penelitian yang dilakukan oleh Taswan (2003), Sujoko (2007); serta Andri Rachmawati dan Hanung Triatmoko (2007) menemukan bahwa struktur kepemilikan saham (insider ownership) berpengaruh positif terhadap nilai perusahaan. Sedangkan penelitian yang dilakukan Hastuti (2005) menemukan bahwa tidak terdapat hubungan yang signifikan antara struktur kepemilikan dengan nilai perusahaan. 
I Made Dharma Putra Utama, Pengaruh Dividen,Utang ...

Total pengembalian (return) kepada pemegang saham selama waktu tertentu terdiri dari peningkatan harga saham ditambah dividen yang diterima. Apabila perusahaan menetapkan dividen yang lebih tinggi dari tahun sebelumnya, maka return yang diperoleh investor akan semakin tinggi. Kebijakan dividen merupakan kunci return yang didapatkan investor berupa dividen. Menilai baik buruknya kinerja perusahaan sering terlihat pada kebijakan dividennya (Khan et al., 2011). Keputusan penentuan jumlah persebaran laba ditahan dengan besar dividen yang dibagikan ialah ciri khas kebijakan dividen (Purwanti, 2010).

Selain itu kebijakan hutang juga dapat dihubungkan dengan nilai perusahaan. Kebijakan hutang merupakan kebijakan perusahaan tentang seberapa jauh sebuah perusahaan menggunakan pendanaan hutang. Dengan adanya hutang, semakin tinggi proporsi hutang maka semakin tinggi harga saham perusahaan tersebut. Penelitian yang dilakukan oleh Arie dan rohman (2012) dan Lihan dan Bandi (2010) menunjukan bahwa keputusan pendanaan berpengaruh positif terhadap nilai perusahaan.

Perusahaan yang porsi utangnya tinggi mengindikasikan bahwa perusahaan tersebut mampu untuk membayar kewajiban-kewajiban di masa yang akan datang sehingga akan mengurangi ketidakpastian investor terhadap kemampuan perusahaan dalam memberikan pengembalian atas modal yang telah disetorkan investor (Brigham dan Houston, 2001 dalam Afzal dan Rohman, 2012). Kepercayaan investor ini akan ditunjukan melalui pembeliaan saham perusahaan tersebut yang nantinya akan meningkatkan nilai perusahaan tersebut. 
Sektor property \& real estate merupakan salah satu sektor terpenting di suatu negara. Hal ini dapat dijadikan indikator untuk menganalisis kesehatan ekonomi suatu negara. Menurut Santoso (2009) industri properti dan real estate merupakan salah satu sektor yang memberikan sinyal jatuh atau sedang bangunnya perekonomian suatu negara.

Pada kebijakan dividen dapat dianggap sebagai salah satu komitmen perusahaan untuk membagikan sebagian laba bersih yang diterima kepada para pemegang saham (Suad Husnan, 1998). Dividen merupakan hak pemegang saham biasa (commond stock) untuk mendapatkan bagian dari keuntungan perusahaan. Jika perusahaan memutuskan untuk membagi keuntungan dalam dividen, semua pemegang saham biasanya akan mendapatkan hak yang sama (Jogiyanto). Keputusan dividen dalam penelitian ini menggunakan indikator dividend yield (DY) dan dividend payout ratio (DPR) (Kallapur dan Trombley, 1999 dalam Hasnawati, 2005.Brigham et al. 1999. Fitrijanti dan Hartono dalam Hasnawati, 2005). Dengan demikian aspek penting dari keputusan dividen adalah menentukan alokasi laba yang sesuai diantara pembayaran laba sebagai dividen dengan laba yang ditahan perusahaan sehingga akan berdampak pula pada meningkatnya nilai perusahaan.

Hasil perhitungan diperoleh bahwa tidak ada pengaruh secara statistik signifikan antara Kebijakan Dividen terhadap nilai perusahaan secara parsial. Tidak adanya pengaruh yang signifikan ini mengindikasikan bahwa besar kecilnya ukuran perusahaan tidak mempengaruhi naik turunnya nilai perusahaan. Hasil penelitian ini tidak sesuai dengan penelitian yang dilakukan oleh Taswan (2003) serta Intan 
Rachmawati dan Akram (2007) menemukan bahwa kebijakan dividen berpengaruh terhadap nilai perusahaan. Dengan demikian hipotesis pertama yang menyatakan bahwa terdapat pengaruh keputusan dividen terhadap nilai perusahaan, tidak diterima.

Kebijakan hutang yaitu kemampuan perusahaan dalam pembiayaan hutang. Perusahaan dengan kebijakan hutang yang tinggi akan menanggung monitoring cost yang tinggi juga ini berarti perusahaan dengan Kebijakan hutang yang tinggi akan menyediakan informasi yang lebih luas dan detail untuk memenuhi tuntutan debitur jangka panjang, dibanding dengan perusahaan kebijakan hutang rendah.

Sementara profitabilitas adalah kemampuan perusahaan memperoleh laba dalam hubungan dengan penjualan, total aktiva maupun modal sendiri (Sartono, 2000). Profitabilitas menunjukkan kemampuan perusahaan menghasilkan laba dari aktiva yang dipergunakan.Profitabilitas memiliki pengaruh positif terhadap nilai perusahaan karena laba yang diperoleh perusahaan yang semakin tinggi menyebabkan peningkatan nilai perusahaan. Hasil perhitungan diperoleh bahwa ada pengaruh secara statistik signifikan dan positif antara Profitabilitas terhadap Nilai Perusahaan secara parsial. Adanya pengaruh yang signifikan dan positif ini mengindikasikan bahwa semakin besar keuntungan yang diukur dari profitabilitas perusahaan mempengaruhi semakin meningkatnya nilai perusahaan.

Sebaliknya, semakin rendah keuntungan yang diukur dari profitabilitas perusahaan mempengaruhi semakin menurunnya nilai perusahaan. Hasil temuan ini sesuai dengan penelitian oleh Intan Rachmawati dan Akram (2007) menemukan bahwa ada pengaruh profitabilitas terhadap nilai perusahaan. Dengan demikian 
hipotesis keempat yang menyatakan bahwa terdapat pengaruh positif antara profitabilitas terhadap nilai perusahaan, diterima pengaruh positif antara profitabilitas terhadap nilai perusahaan, diterima.

Tujuan penelitian ini yakni untuk mengetahui signifikansi pengaruh kebijakan dividen, kebijakan utang dan profitabilitas terhadap nilai perusahaan. Hasil penelitian ini diharapkan dapat memberi kontribusi teoritis. Pada Manajemen Keuangan khusunya pada sektor investasi. Penelitian ini juga diharapkan dapat digunakan sebagai salah satu hasil studi empiris dimana nantinya dapat memberikan pemahaman dalam mengembangkan dan mengaplikasikan teori-teori dengan variabel-variabel yang mempengaruhi. Bagi akademisi dan peneliti di bidang keuangan, hasil penelitian ini dapat dijadikan salah satu masukan seputar pengaruh kebijakan dividen, kebijakan hutang dan profitabilitas terhadap nilai perusahaan property/real estate pada bursa efek indonesia (BEI).

Penelitian Lihan dan Bandi (2010) dan Sofyaningsih dan Hardiningsih (2011) menemukan bahwa kebijakan dividen secara positif berpengaruh terhadap nilai perusahaan. Modligani dan Miller berpendapat kebijakan dividen tidak berpengaruh terhadap harga saham atau nilai perusahaan, sedangkan Gordon dan Lintner mengatakan bahwa kebijakan dividen berpengaruh positif terhadap nilai perusahaan. Menurut Agus Sartono (2011:281) menyatakan bahwa pembayaran dividen yang lebih besar cenderung akan meningkatkan harga saham.

Kerangka konseptual yang diajukan sebagai dasar penentu hipotesis ditunjukan pada Gambar 1 sebagai berikut. 
I Made Dharma Putra Utama, Pengaruh Dividen,Utang ...

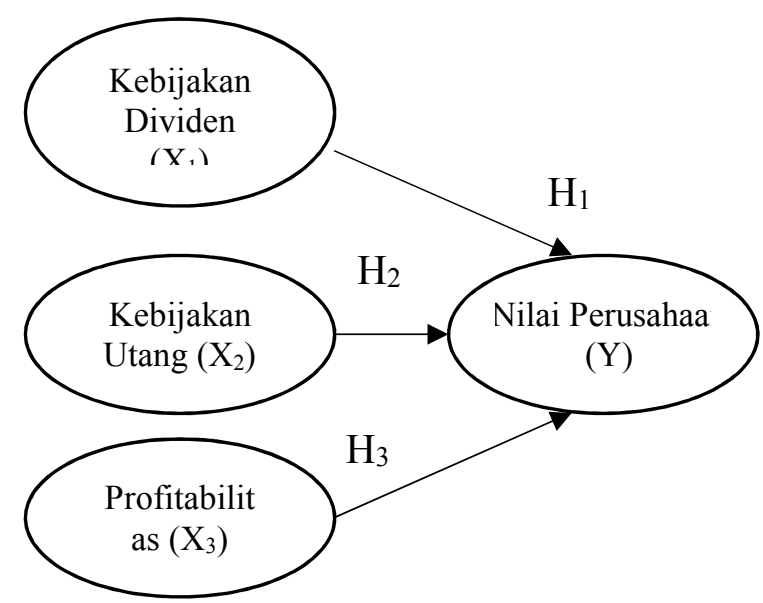

\section{Gambar 1. Kerangka Konseptual Penelitian}

Meningkatnya harga saham berarti meningkatnya nilai perusahaan. Peneliti Wira Adi Darmawan (2010), Nani Martikarini (2013), dan Tri Wahyuni (2013) juga mengatakan bahwa pembagian dividen akan membuat pemegang saham akan mempunyai tambahan return selain capital gain, sehingga hal ini akan mengakibatkan kebijakan dividen yang dikeluarkan akan mempunyai pengaruh terhadap nilai perusahaan tersebut. Berdasarkan pemikiran ini maka dikembangkan hipotesis sebagai berikut:

$\mathrm{H}_{1}$ : Kebijakan deviden berpengaruh positif terhadap nilai perusahaan

Penelitian yang dilakukan oleh Arie dan rohman (2012) dan Lihan dan Bandi (2010) menunjukan bahwa keputusan pendanaan berpengaruh positif terhadap nilai perusahaan. Perusahaan yang porsi utangnya tinggi mengindikasikan bahwa perusahaan tersebut mampu untuk membayar kewajiban-kewajiban di masa yang akan datang sehingga akan mengurangi ketidakpastian investor terhadap kemampuan perusahaan dalam memberikan pengembalian atas modal yang telah disetorkan investor (Brigham dan Houston, 2001 dalam Afzal dan Rohman, 2012). 
Kepercayaan investor ini akan ditunjukan melalui pembeliaan saham perusahaan tersebut yang nantinya akan meningkatkan nilai perusahaan tersebut.

Kebijakan hutang termasuk kebijakan pendanaan yang bersumber dari eksternal. Sebagian beranggapan bahwa kebijakan hutang mempunyai pengaruh positif terhadap nilai pajak karena dapat menghemat pajak. Hal ini sesuai dengan pernyataan Modligani dan Miller dalam Rahmawati (2012) bahwa dengan adanya keuntungan dari pengurangan pajak karena adanya bunga yang dibayarkan akibat penggunaan hutang tersebut mengurangi penghasilan yang terkena pajak. Menurut Darmawan (2010) menyatakan bahwa kebijakan hutang perlu dikelola karena yang terlampau tinggi dapat menurunkan nilai perusahaan. Menurut Weston dan Copeland dalam Martikarini (2013) menyatakan bahwa kebijakan hutang perlu dikelola karena penggunaan hutang yang tinggi akan meningkatkan nilai perusahaan karena penggunaan hutang dapat menghemat pajak.

Hasil penelitian yang diungkapkan oleh Titin Herawati (2013) menyatakan bahwa kebijakan hutang berpengaruh positif terhadap nilai perusahaan, sedangkan peneliti Apriliana Nuzul Rahmawati (2012) mengungkapkan bahwa kebijakan hutang mempunyai pengaruh negatif terhadap nilai perusahaan karena semakin tinggi perusahaan menggunakan kebijakan hutang maka akan menurunkan nilai perusahaan. Berdasarkan pemikiran ini maka dikembangkan hipotesis sebagai berikut:

$\mathrm{H}_{2}$ : Kebijakan utang berpengaruh positif terhadap nilai perusahaan

Penelitian yang dilakukan oleh Deltiana (2011), Sofyaningsih dan Hardiningsih (2011) menunjukan bahwa profitabilitas berpengaruh positif terhadap 
I Made Dharma Putra Utama, Pengaruh Dividen,Utang ...

nilai perusahaan. Profitabilitas yang tinggi mencerminkan kemampuan perusahaan dalam menghasilkan keuntungan yang tinggi bagi para pemegang saham. Dengan rasio profitabilitas yang tinggi akan menarik minat para investor untuk menanamkan modalnya di perusahaan (Sofyaningsih dan Hardiningsih, 2011). Semakin diminatinya saham perusahan tersebut oleh para investor makan akan mengakibatkan nilai perusahaan tersebut akan meningkat. Kekuatan laba mengacu pada tingkat laba perushaaan yang diharapkan terjadi pada masa depan. Kekuatan laba diakui sebagai faktor utama dalam penilaian perusahaan (Subramanyam dan Wild yang dialihbasakan oleh Dewi Yanti (2012:170).

Profitabilitas atau laba merupakan daya tarik bagi para investor sebelum menanamkan saham di perusahaan tersebut. Investor akan terlebih dahulu melihat tingkat profitabilitas untuk menilai nilai perusahaan tersebut. Seperti yang diteliti oleh Nani Martikarini (2013), Wira Adi Darmawan (2010), Novita Santi Puspita (2011), dan Tri Wahyuni (2013) yang mengungkapkan bahwa profitabilitas berpengaruh positif terhadap nilai perusahaan. Ada juga peneliti yang mengungkapkan bahwa profitabilitas berpengaruh negatif terhadap nilai perusahaan. Seperti penelitian yang dilakukan oleh Titin Herawati (2013) yang mengungkapkan bahwa profitabilitas berpengaruh negatif terhadap nilai perusahaan, dimana profitabilitas meningkat maka nilai perusahaan justru mengalami penurunan. Hal ini dikarenakan oleh peningkatan profitabilitas perusahaan akan menjadikan laba perlembar saham perusahaan meningkat, tetapi dengan peningkatan profitabilitas belum tentu harga saham perusahaan itu meningkat sehingga apabila laba perlembar saham meningkat tetapi harga saham 
tidak meningkat maka itu akan membuat nilai perusahaan menjadi turun. Berdasarkan pemikiran ini maka dikembangkan hipotesis sebagai berikut:

$\mathrm{H}_{3}$ : Profitabilitas berpengaruh positif terhadap nilai perusahaan

\section{METODE PENELITIAN}

Lokasi penelitian ini adalah perusahaan property \& real estate di Bursa Efek Indonesia pada tahun 2012-2016 dan dapat diakses dengan alamat website www.idx.co.id. Objek penelitian ini adalah nilai perusahaan dan variabel yang mempengaruhi perusahaan property \& real estate di Bursa Efek Indonesia periode 2012-2016. Proxy dari kebijakan dividen yang dipilih untuk penelitian ini adalah Dividend Payout Ratio (DPR), dengan alasan bahwa, DPR lebih dapat menggambarkan perilaku oportunistik manajerial yaitu dengan melihat berapa besar keuntungan yang dibagikan kepada shareholders sebagai dividen dan berapa yang disimpan di perusahaan. Rumus dividend payout ratio adalah sebagai berikut:

$$
D P R=\frac{\text { Dividen per lembar saham }}{\text { Laba per lembar saham }} \times 100 \%
$$

Proxy dari kebijakan hutang pada penelitian ini adalah Debt to Equity Ratio (DER). Tujuan dari rasio ini adalah untuk mengukur kemampuan perusahaan dalam membayar hutang-hutang yang dimilikinya dengan modal atau ekuitas yang ada. Rumus debt to equity ratio adalah sebagai berikut:

$$
D E R=\frac{\text { Total Utang }}{\text { Total Modal }} x 100 \%
$$

Rasio profitabilitas menghitung kemampuan perusahaan dalam mendapatkan keuntungan. Dalam penelitian ini digunakan proxy Return on Equity (ROE) untuk mengukur profitabilitas perusahaan. Rasio ROE adalah rasio laba bersih terhadap 
ekuitas saham biasa, yang mengukur tingkat pengembalian atas investasi dari pemegang saham biasa. Rumus ROE dapat dihitung sebagai berikut:

$$
R O E=\frac{\text { Net Income }}{\text { Ekuitas Saham Biasa }} x 100 \%
$$

Variabel terikat adalah variabel yang variabelitasnya diamati dan diukur untuk menentukan pengaruh yang disebabkan oleh variabel bebas. Dalam penelitian ini variabel dependen yang digunakan adalah nilai perusahaan.

$$
E P S=\frac{\text { Ekuitas Saham Biasa }}{\text { Jumlah lembar saham biasa yang beredar }} \times 100 \%
$$

Penelitian ini yang menjadi populasi adalah perusahaan property \& real estate periode 2012 sampai 2016 dan memiliki ukuran populasi (population size) berjumlah sebanyak 48 perusahaan di Bursa Efek Indonesia (BEI). Sampel yang digunakan dalam penelitian ini adalah perusahaan property \& real estate di Bursa Efek Indonesia. Adapun metode penentuan sampel yang digunakan dalam penelitian ini adalah metode non-probabilty sampling dengan teknik purposive sampling. Kriteria-kriteria yang di pertimbangkan untuk pengambilan sampel dalam penelitian ini adalah sebagai berikut. 1). Perusahaan property \& real estate di Bursa Efek Indonesia secara berturut-turut pada periode 2012-2016; 2). Perusahaan yang mempublikasikan laporan tahunan (annual report) dan laporan keuangan tahunan pada tahun 2012-2016 pada website BEI; 3). Data yang dimiliki perusahaan lengkap sesuai dengan variabel-variabel yang digunakan pada penelitian.

Metode pengumpulan dalam pada penelitian ini menggunakan metode observasi non partisipan dimana penelitian ini tidak terlihat secara langsung, dan penelitian ini hanya mengamati secara independen. Penelitian ini melakukan 
pengamanan dan pencatatan pada data-data terkait pada perusahaan property $\&$ real estate dengan cara mencatat, mengamati, serta mempelajari dari eksporasi laporan keuangan tahunan perusahaan property \& real estate. Pada penelitian ini jenis data yang digunakan adalah data kuantitatif dan data kualitatif. Data kuantitatif merupakan data data yang berupa angka. Data dalam penelitian ini adalah laporan keuangan perusahaan property \& real estate pada tahun 2012 hingga 2016. Data kualitatif merupakan suatu data yang berupa pendapat (pernyataan) atau jugdement sehingga tidak berupa angka akan tetapi berupa kata-kata atau kalimat (Siregar, 2010:129). Data kualitatif yang digunakan pada penelitian ini meliputi gambaran umum dari perusahaan property \& real estate.

Penelitian ini menggunakan uji asumsi klasik terlebih dahulu kemudian analisis yang digunakan untuk menyelesaikan permasalahan dalam penelitian ini yaitu regresi linear berganda. Adapun persamaan regresi linear berganda rumusnya sebagai berikut:

$$
\mathrm{Y}=\mathrm{a}+\mathrm{b}_{1} \mathrm{x}_{1}+\mathrm{b}_{1} \mathrm{x}_{2}+\mathrm{b}_{1} \mathrm{x}_{3}+\mathrm{e}
$$

\section{Keterangan :}

$$
\begin{array}{ll}
\mathrm{Y} & =\text { Nilai Perusahaan. } \\
\mathrm{X}_{1} & =\text { Kebijakan Dividen } \\
\mathrm{X}_{2} & =\text { Kebijakan Hutang. } \\
\mathrm{X}_{3} & =\text { Profitabilitas. } \\
\mathrm{a} & =\text { Konstanta } \\
\mathrm{e} & =\text { Standar error }
\end{array}
$$

\section{HASIL DAN PEMBAHASAN}

Daerah atau wilayah penelitian adalah Bursa Efek Indonesia (BEI), khusunya adalah perusahaan yang terdaftar di BEI dan masuk dalam pemeringkatan tahun 2012-2016. Penelitian ini menggunakan sampel yang memenuhi kriteria pemilihan 
I Made Dharma Putra Utama, Pengaruh Dividen,Utang ...

sampel yang telah ditentukan sebelumnya. Berdasarkan observasi penelitian yang dilakukan, maka perusahaan yang dapat dijadikan sampel adalah sebanyak 7 perusahaan.

Pertama dilakukan uji asumsi klasik terlebih dahulu. Berdasarkan hasil analisis, diperoleh nilai Asymp. Sig. (2-tailed) dari model persamaan yang diuji sebesar 0,590 lebih besar dari 0,05. Hal ini menunjukkan data yang digunakan dalam penelitian ini telah berdistribusi normal. Berdasarkan hasil uji autokorelasi di atas, nilai $\mathrm{dw}$ yang dihasilkan sebesar 1,896 . Oleh karena jumlah $\mathrm{n}=35$ dan $\mathrm{k}=$ 3, diperoleh nilai $\mathrm{d}_{\mathrm{L}}=1,2833$ dan dan nilai 4- $\mathrm{d}_{\mathrm{u}}=2,3472$, maka dapat dirumuskan kriteria $\mathrm{d}_{\mathrm{u}}<\mathrm{dw}<4-\mathrm{d}_{\mathrm{u}}$ yaitu $(1,6528<1,896<2,3472)$. Hal ini menunjukkan data yang digunakan pada penelitian ini bebas dari autokorelasi. Menunjukkan bahwa koefisien Tolerance semua variabel lebih besar dari 0,10 dan nilai VIF yang lebih kecil dari 10. Hasil tersebut menunjukkan bahwa tidak terdapat gejala multikolinieritas dalam model regresi yang dibuat.

Berdasarkan hasil uji heteroskedastisitas, dapat diketahui nilai signifikansi dari variabel kebijakan dividen sebesar 0,227 (>0,05), nilai signifikansi dari variabel kebijakan utang sebesar 0,195 $(>0,05)$, dan nilai signifikansi dari variabel profitabilitas yakni sebesar $0,356(>0,05)$. Oleh karena nilai signifikansi dari masing-masing variabel independen terhadap variabel absolute residual berada diatas 0,05 maka dapat disimpulkan bahwa data yang digunakan pada penelitian ini tidak terdapat masalah heteroskedastisitas.

Analisis regresi linier berganda digunakan untuk mengetahui arah serta besarnya pengaruh dan signifikansi antara kebijakan dividen, kebijakan utang, dan 
profitabilitas terhadap nilai perusahaan property pada tahun 2012-2016. Hasil perhitungan regresi linier berganda ini dihitung menggunakan SPSS.

Tabel 2.

Hasil Uji Analisis Regresi Linier Berganda

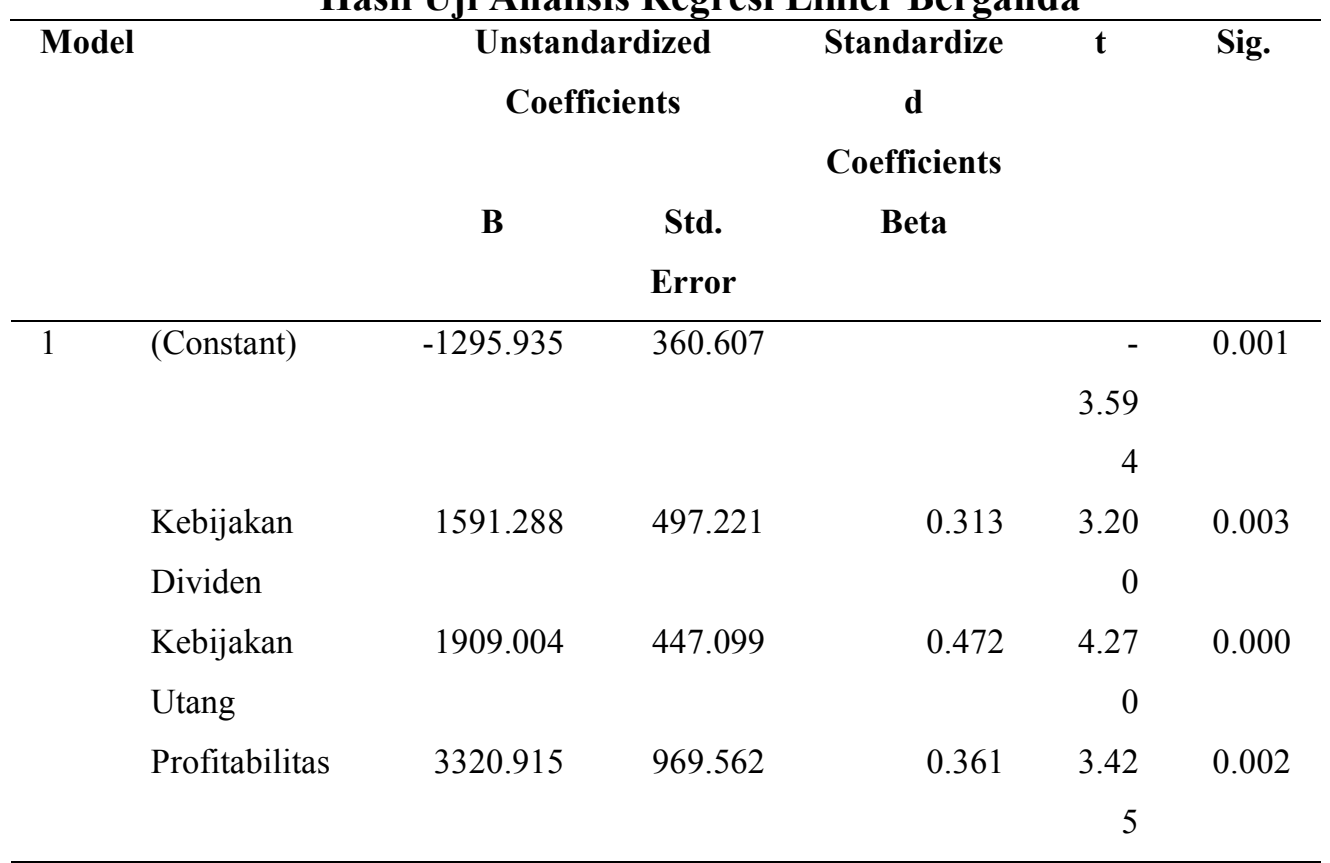

Sumber: Data diolah, 2018

Berdasarkan Tabel 2. yang menyajikan hasil dari analisis regresi berganda, maka persamaan regresi yang digunakan dalam penelitian ini dapat ditulis sebagai berikut:

$$
Y=-1,295,935+1,591,288 X_{1}+1,909,004 X_{2}+3320.915 X_{3}
$$

Kebijakan dividen yang diproksikan dengan variabel dividend payout ratio (DPR) secara parsial memiliki pengaruh signifikan terhadap nilai perusahaan properti yang diproksikan dengan PBV. Dapat dilihat bahwa variabel DPR memiliki nilai $t$ hitung yang lebih besar dari t tabel $(3,200>2,080)$ dengan nilai signifikansi 0,003 yang lebih kecil dari 0,05. Hasil ini menunjukan bahwa kebijakan dividen yang diwakili oleh DPR berpengaruh positif dan signifikan terhadap nilai 
perusahaan yang diwakilkan dengan PBV. Hal tersebut menunjukkan DPR diterima.

Hasil penelitian tersebut sejalan dengan teori bird-in-the-hand yang diajukan oleh Myron Gordon dan John Lintner (1959) dalam Brigham (2001;67), yang menyatakan bahwa nilai perusahaan akan dimaksimumkan oleh rasio pembayaran dividen yang tinggi, karena investor menganggap bahwa resiko dividen tidak sebesar kenaikan biaya modal, sehingga investor lebih menyukai keuntungan dalam bentuk dividen daripada keuntungan yang diharapkan dari kenaikan nilai modal. Hasil penelitian ini juga didukung oleh hasil penelitian Susanti (2010), Perdana (2012), yang menyatakan bahwa kebijakan dividen berpengaruh signifikan dan positif terhadap nilai perusahaan.

Kebijakan utang dalam penelitian sebelumnya memiliki pengaruh positif signifikan terhadap nilai perusahaan. Teori keagenan (agency theory) menjelaskan bahwa kebijakan utang yang diwakilkan oleh DER memiliki pengaruh yang searah terhadap nilai perusahaan yang diwakilkan oleh PBV.

Dapat dilihat bahwa variabel DER memiliki nilai t hitung yang lebih besar dari t tabel $(4,270>2,080)$ dengan nilai signifikansi 0,000 yang lebih kecil dari 0,05. Hasil ini menunjukkan bahwa kebijakan utang yang diwakilkan oleh DER berpengaruh positif dan signifikan terhadap nilai perusahaan yang diwakilkan dengan PBV. Hal tersebut menunjukkan DER diterima.

Hasil penelitian ini sesuai dengan penelitian yang dilakukan oleh Mulianti (2010) yang menyatakan bahwa kebijakan hutang berpengaruh positif terhadap nilai perusahaan. Hal ini sejalan dengan Agency Teory yang menggambarkan 
hubungan antara agent (manajer) dan principal (pemegam saham). Manajer harus mengambil keputusan bisnis terbaik untuk meningkatkan kekayaan pemegang saham, tidak terkecuali pengambilan keputusan untuk memenuhi modal yang dibutuhkan perusahaan.

Modal yang besar biasanya dipenuhi manajemen dengan menggunakan sumber dana eksternal atau dengan kata lain berhutang. Hasil ini didukung dengan asumsi tanpa pajak dan pasar sempurna, nilai pasar perusahaan bersifat tidak tergantung pada keputusan pendanaan atau struktur modal. Hal ini sejalan dengan Jensen (1986) yang menyatakan bahwa hutang dapat digunakan untuk mengendalikan penggunaan free cash flow secara berlebihan oleh manajemen, dengan demikian semakin tinggi hutang maka semakin tinggi nilai perusahaan, karena perusahaan akan memperbaiki kinerjanya dimana dengan hutang yang tinggi perusahaan akan termotivasi untuk meningkatkan labanya.

Berdasarkan hasil penelitian yang telah dilakukan ditemukan bahwa profitabilitas yang diwakilkan oleh $\mathrm{ROE}$ berpengaruh positif dan signifikan terhadap nilai perusahaan yang diwakilkan oleh PBV. Dimana dapat dilihat bahwa variabel ROE memiliki nilai t hitung yang lebih besar dari t tabel $(3,425>2,080)$ dengan nilai signifikansi 0,002 yang lebih kecil dari 0,05 . Hasil ini menunjukkan bahwa profitabilitas yang diwakilkan oleh ROE berpengaruh positif dan signifikan terhadap nilai perusahaan yang diwakilkan dengan PBV. Hal tersebut menunjukkan ROE diterima.

Hasil konsisten dengan penelitian Ni Wayan Yuniasih dan Made Gede Wirakusuma yang menyatakan bahwa ROA berpengaruh signifikan terhadap nilai 
perusahaan dan nilai saham dapat tercermin dari nilai saham perusahaan tersebut. Apabila profitabilitas di dalam perusahaan yang dicerminkan oleh return on assets (ROA) tinggi maka nilai perusahaan juga akan semakin meningkat karena nilai perusahaan ditentukan oleh earnings power dari aset perusahaan. Semakin tinggi earning power maka semakin efisien perputaran aset dan semakin tinggi profit margin yang diperoleh perusahaan.

Menurut Brigham, Houston dan Mulyadi menunjukan bahwa profitabilitas merupakan salah satu mekanisme corporate governance yang mampu meningkatkan nilai perusahaan. Jika dilihat dari arah koefisiennya maka pengaruhnya adalah positif, yang artinya semakin tinggi profitabilitas maka akan semakin tinggi juga nilai perusahaan. Apabila dilihat dari koefisiennya maka pengaruhnya adalah positif, yang artinya semakin tinggi profitabilitas maka akan semakin tinggi juga nilai perusahaan. Begitu pula sebaliknya, semakin rendah profitabilitas maka akan semakin rendah juga nilai perusahaan tersebut. Dalam hal ini profitabilitas tentunya akan membuat para manajer akan berusaha untuk meningkatkan nilai kekayaannya sebagai pemegang saham perusahaan tersebut, yang pada akhirnya juga akan meningkatkan nilai perusahaan. Dengan demikian, profitabilitas mampu menjadi mekanisme untuk meningkatkan nilai perusahaan.

\section{SIMPULAN DAN SARAN}

Berdasarkan hasil analisis data serta pembahasan mengenai pengaruh masingmasing variabel yang telah dipaparkan, maka dapat ditarik kesimpulan sebagai berikut: 1). Kebijakan dividen yang diproksikan dengan variabel dividend payout ratio (DPR) secara parsial memiliki pengaruh signifikan terhadap nilai perusahaan 
property yang diproksikan dengan PBV; 2). Kebijakan utang dalam penelitian ini memiliki pengaruh positif signifikan terhadap nilai perusahaan dimana, kebijakan utang yang diproksikan oleh DER memiliki pengaruh positif dan signifikan terhadap nilai perusahaan yang diwakilkan oleh PBV; 3). Berdasarkan hasil penelitian yang telah dilakukan ditemukan bahwa profitabilitas yang diproksikan oleh ROE berpengaruh positif dan signifikan terhadap nilai perusahaan yang diwakilkan oleh PBV.

Saran yang dapat diberikan berkaitan dengan penelitian ini Penelitian selanjutnya dapat menggunakan lokasi penelitian lain, tidak hanya pada perusahaan property yang terdaftar di BEI, tetapi juga industri dari sektor lainnya atau berasal dari semua jenis perusahaan publik atau dapat juga membandingkan antar jenis perusahaan publik mengenai kebijakan perusahaan tersebut dan pengaruhnya terhadap nilai perusahaan. Penelitian ini dilakukan dalam periode 2012-2016. Kebijakan yang diwakili oleh DPR berpengaruh positif signifikan terhadap nilai perusahaan yang diwakili oleh PBV, maka kepada pihak perusahaan disarankan untuk terus menjaga dan meningkatkan nilai perusahaannya melalui profit yang didapat, karena melalui profit atau laba tersebut perusahaan akan menjalankan kegiatan operasionalnya dengan baik dan efisien.

Kebijakan utang yang diwakilkan dengan DER berpengaruh positif signifikan terhadap nilai perusahaan yang diwakilkan dengan PBV, maka kepada pihak perusahaan karena memiliki nilai DER yang tinggi disarankan agar selalu berhatihati didalam meminjam pinjaman. Profitabilitas yang dalam penelitian ini diwakilkan dengan ROE berpengaruh positif signifikan terhadap nilai perusahaan 
I Made Dharma Putra Utama, Pengaruh Dividen,Utang ...

yang diwakilkan dengan PBV, maka kepada pihak perusahaan di harapkan untuk meningkatkan profit perusahaan hal tersebut dikarenakan, semakin tinggi nilai profit yang didapat maka akan semakin tinggi nilai perusahaan. Karena profit yang tinggi akan memberikan indikasi prospek perusahaan yang baik sehingga dapat memicu investor untuk ikut meningkatkan permintaan saham pada perusahaan tersebut di kemudian hari.

\section{REFERENSI}

Afzal, Arie; Rohman, Abdul (2012). Pengaruh Keputusan Investasi, Keputusan Pendanaan, dan Kebijakan Dividen Terhadap Nilai Perusahaan, Diponegoro Journal Of Accounting, 1(2),pp : 1-9.

Atmaja, Lukas Setia. Journal of Academic Research in Accounting. Finance and Management Sciences, 2(2), pp: 93- 108.

Ary, Tatang Gumanti (2013). Kebijakan Dividen: Teori, Empiris dan Implikasi, UPP STIM YKPN, Yogyakarta.

Bangun, Nurainun dan Sinta Wati. (2007). Analisis Pengaruh Profitabilitas dan Kebijakan Dividen terhadap Nilai Perusahaan Perdagangan, Jasa dan Investasi yang Terdaftar di Bursa Efek Jakarta. Jurnal Akuntansi/Tahun, 9(2), pp : 107-120.

Brigham, Eugene F dan Joel F Houston. (2003). Fundamentals of Financial Management: Dasar-Dasar Manajemen Keuangan. Buku Satu Edisi Kesepuluh. Jakarta: Salemba Empat.

Brigham, Eugene F dan Joel F Houston, (2007). Essentials of Financial Management. Singapore: Cengage Learning Asia, Ltd.

Deitiana, Titi. (2011). Pengaruh Rasio Keuangan, Pertumbuhan Penjualan dan Dividen Terhadap Harga saham. Jurnal Bisnis dan Akuntansi, 13(1), pp: 57-66.

Dj, Alfredo, Mahendra; Artini, L.G.S.; Suarjaya Gede, A.A. (2012). Pengaruh Kinerja Keuangan Terhadap. Nilai Perusahaan Pada Perusahaan Manufaktur di Bursa Efek Indonesia. Jurnal Manajemen, Strategi Bisnis, dan Kewirausahaan, 6(2), pp : 180-189.

Dwi, Martini. (2016). Akuntansi Keuangan Menengah. Jakarta: Salemba Empat. 
Efni, Yulia; Hadiwidjojo, Djumilah; Salimm Ubud; Rahayu, Mintari (2011). Keputusan Investasi, Keputusan Pendanaan dan Kebijakan Dividen Pegaruhnya Terhadap Nilai Perusahaan, Jurnal Manajemen Vol. 1(1), pp : 128-141.

Endang \& Minaya. (2003). Pengaruh Insider Ownership, Dispersi Of Ownership, Free Cash Flow, Collaterizable Assets dan Tingkat Pertumbuhan terhadap Kebijakan Dividen. Jurnal Ekonomi dan Bisnis, 14(21), 1-18.

Fama, E.F. French, Kenneth R., (1998). Taxes. Financing Decision dan Firm Value. The Journal of Finance, 53(3),pp : 1-34.

Ghozali. (2007). Aplikasi Analisis Multivariate dengan Program SPSS. Cetakan Keempat. Semarang: BPUNDIP.

Gitman, L.J. (2003). Principle of Managerial Finance. 10 edition, USA: Addison Wesley.

Gusaptono, R.H. (2010). Faktor-Faktor yang Mendorong Penciptaan Nilai Perusahaan di BEI. Buletin Ekonomi, 8(2), pp: 149-158.

Hair, J.F., R.E. Anderson dan W.C. Black. (2006). Multivariate Data Analysis. Sixth Edition. New Jersey: Prentice Hall International, Inc.

Hatta, Atika J. (2002). Faktor-Faktor yang Mempengaruhi Kebijakan Dividen, Jurnal Akuntansi dan Auditing indonesia, 6(2), pp: 1-22.

Hermi. (2004). Hubungan Laba Bersih dan Arus Kas Operasi terhadap Dividen Kas pada Perusahaan Perdagangan Besar Barang Produksi di BEJ pada Periode 1999-2002. Media Riset Akuntansi, Auditing, dan Informasi, 4(3), pp : 247-258.

Husnan, Suad. (1998) Manajemen Keuangan: 2002. Manajemen Keuangan. Edisi kedua. Yogyakarta: Andi.

Indrajaya, Glenn, Herlina, dan Rini Setiadi. (2011). Pengaruh Struktur Aktiva, Ukuran Perusahaan, Tingkat Pertumbuhan, Profitabilitas dan Risiko Bisnis Terhadap Struktur Modal: Studi Empiris Pada Perusahaan Sektor Pertambangan Yang Listing di Bursa Efek Indonesia Periode 2004-2007. Akurat Jurnal Ilmiah Akuntansi, 3(6), pp : 1-23.

Ismiyanti, Fitri dan M.M. Hanafi. (2003). Lepemilikan Manajerial, Kepemilikan Institusional, Risiko, Kebijakan Utang dan Kebijakan Dividen: Analisis Persamaan Simultan. Prosiding Simposium Nasional Akuntansi VI, pp : 260-277. 
Kallapur, S,m dan M.A. Trombley. (1999). The Association Between Investment Opportunity Set Proxies and Realized Growth. Journal of Business and Accounting 26, pp: 505-519.

Kennedy J.S.P. (2003). “Analisis Pengaruh dari Return on Asset, Return on Equity, Earnings Per Share, Profit Margin, Asset Turnover, Rasio Leverage dan Debt to Equity Ratio terhadap 17 Return Saham (Studi terhadap Sahamsaham yang Termasuk dalam LQ-45 di BEJ Tahun 2001)". Tesis tidak dipublikasikan, Program Pascasarjana Universitas Indonesia, Jakarta.

Kesuma, Ali. (2009). Analisis Faktor-Faktor yang Mempengaruhi Struktur Modal Serta Pengaruhnya Terhadap Harga Saham Perusahaan Real Estate yang Go Public di Bursa Efek Indonesia. Jurnal Manajemen dan Kewirausahaan, 11 (1), pp : 38-43.

Kieso, Donald E., Jerry J. Weygandt dan Terry D. Warfeild. (2007). Intermediate Accounting. 12 Edition, USA: Wiley International Edition.

Mahadwartha, Putu A. dan Jogiyanto Hartono. (2002). Uji Teori Keagenan dalam Hubungan Interdependensi antara Kebijakan Hutang dengan Kebijakan Dividen. Prosiding Simposium. Nasional Akuntansi V, pp: 635-647.

Margareta, Farah. (2004). Teori dan Aplikasi Manajemen Keuangan: Investasi dan Sumber Dana Jangka Pendek. Jakarta: PT. Grasindo.

Megginson, William L. (1997). Corporate Finance Theory. Massachusetts; Addison - Wesley.

Nuringsih, Kartika. (2005). Analisis Pengaruh Kempemilikan Managerial, Kebijakan Hutang, ROA dan Ukuran Perusahaan terhadap kebijakan Dividen: Studi 1995-1996. Jurnal Akuntansi dan Keuangan Indonesia, Juli-Desember, Vol 2(2), pp: 103-123.

O'Connor, Melvin. C. (1973). On The Usefulness of Financial Ratios to Investors in Common Stock. The Accounting Review. 5(2), pp: 339-352.

Pankoff dan Vergill. (1970). On The Usefullness of Financial Statement Information: A Suggested Research Approach. Accounting Review.3(3), pp : 269-279.

Parawiyati, Ambar W.H., Edi S. (2000). "Penggunaan Informasi Keuangan untuk Memprediksi Keuntungan Investasi bagi Investor di Pasar Modal”. Jurnal Riset Akuntansi Indonesia, 3(2), pp : 214-228. 
Prihantoro. (2003). Estimasi Pengaruh Dividen Payout Ratio pada Perusahaan Publik di Indonesia. Jurnal Ekonomi dan Bisnis, 14(1), pp : 7-14.

Putri, I, F. \& Nasir, M. (2007). Analisis Persamaan Simultan Kepemilikan Manajerial, Kepemilikan Institucional, Risiko, Kebijakan Utang, dan Kebijakan Dividen Dalam Perspektif Teori Keagenan. Simposium Nasional Akuntansi IX. Padang.

Sayidah, Nur dan Diyah Pujiati. (2008). Corporate Governance dan Rasio Utang Perusahaan. Ventura, 11 (2), pp : 299-315.

Silalahi, D. (1991). "Beberapa Faktor yang Mempengaruhi Perubahan Harga Saham (Studi pada Pasar Modal Indonesia)". Tesis tidak dipublikasikan. Program Pascasarjana Universitas Airlangga, Surabaya.

Smith, Jay M. Dan K.F Skousen. (1992). Akuntansi Intermediate. Edisi 9, Jakarta: Erlangga.

Sudarsi, Sri. (2002). Analisis Faktor-Faktor yang Mempengaruhi Dividen Payout Ratio pada Industri Perbankan yang Listed di Bursa Efek Jakarta. Jurnal Bisnis dan ekonomi, 2 (1), pp : 1-13.

Suharli, M. (2007). Pengaruh Profitabilitas dan Invesment Opportunity Set terhadap Kebijakan Dividen Tunai dengan Likuiditas sebagai Variabel Penguat. Jurnal Akuntansi dan Keuangan, 9 (1), pp: 9-17.

Sunarto \& Kartika, A. (2003). Analisis Faktor-faktor yang Mempengaruhi Dividen Kas. Jurnal Ekonomi dan Bisnis, 8 (1), pp : 1-13.

Suryabrata, Sumadi. (2005). Metodologi Penelitian. Jakarta: PT. Raja Grafindo Persada.

Sarwono, Jonathan. (2010). PASW Statistics 18: Belajar Statistik Menjadi Mudah dan Cepat. Yogyakarta: CV Andi Offset.

Suwardjono.2003. Akuntansi Pengantar. Yogyakarta: BPFE Yogyakarta.

Syamsuddin, Lukman. (2009). Manajemen Keuangan Perusahaan (Konsep Aplikasi Dalam Perencanaan Pengawasan dan Pengambilan Keputusan). Jakarta: Raja Grafindo Persada.

Tarjo dan Jogiyanto, Hartono. (2003). Analisis Free Cash Flow dan Kepemilikan Manajerial Terhadap Kebijakan Utang Pada Perusahaan Publik di Indonesia. Prosiding Simposium Nasional Akuntansi VI, pp : 278-295.

Usunariyah. (2003). Pengantar Pasar Modal. Yogyakarta: UPP MPP YKPN. 
I Made Dharma Putra Utama, Pengaruh Dividen,Utang ...

Wahidawati. (2002). Kepemilikan Manajerial dan Agency Conflicts: Analisis Persamaan Simultan Non Liner dari Kepemilikan Manajerial, Penerimaan Risiko, Kebijakan Utang dan Kebijakan Dividen. Prosiding Simposium Nasional Akuntansi $V$, pp : 601-623.

Wahyudi, Untung; Prawestri, Hartini Prasetyaning. (2006). Implikasi Struktur Kepemilikan terhadap Nilai Perusahaan dengan Keputusan Keuangan Sebagai Variabel Intervening. Simposium Nasional Akuntansi (SNA) IX, Padang, 2006.

Weston, Fred J dan Eugene F Brigham. (2005). Dasar-Dasar Manajemen Keuangan Jilid 2 9th ed. Jakarta: Erlangga.

Wiagustini, Ni Luh Putu. (2014). Manajemen Keuangan. Denpasar: Udayana University Press.

Wiagustini, Luh Putu. (2010). Dasar - Dasar Manajemen Keuangan. Denpasar: Udayana University Press.

Wijaya, Lihan; Bandi; Wibawa, Anas. (2006). Pengaruh Keputusan Investasi, Keputusan Pendanaan, dan Kebijakan Dividen terhadap Nilai Perusahaan, Simposium Nasional Akuntansi XIII, Purwokerto, 2010.

Yunita, N. S. (2008). Pengaruh Aliran Kas Bebas, Profitabilitas, dan Utang terhadap Dividen Payout Ratio. Skripsi. Jurusan Akuntansi. Universitas Brawijaya. Malang. 